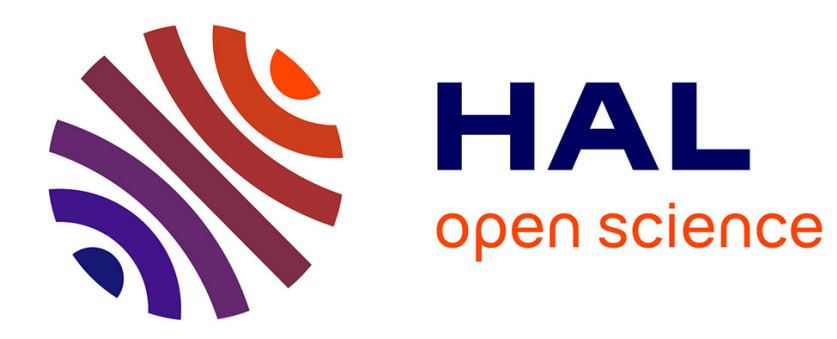

\title{
Forum Section The Study of EU Public Policy
}

Fabio Franchino

\section{To cite this version:}

Fabio Franchino. Forum Section The Study of EU Public Policy. European Union Politics, 2005, 6 (2), pp.243-252. 10.1177/1465116505051985 . hal-00571711

\section{HAL Id: hal-00571711 https://hal.science/hal-00571711}

Submitted on 1 Mar 2011

HAL is a multi-disciplinary open access archive for the deposit and dissemination of scientific research documents, whether they are published or not. The documents may come from teaching and research institutions in France or abroad, or from public or private research centers.
L'archive ouverte pluridisciplinaire HAL, est destinée au dépôt et à la diffusion de documents scientifiques de niveau recherche, publiés ou non, émanant des établissements d'enseignement et de recherche français ou étrangers, des laboratoires publics ou privés. 
EUP

European Union Politics

DOI: 10.1177/1465116505051985

Volume 6 (2): 243-252

Copyright@ 2005

SAGE Publications

London, Thousand Oaks CA,

New Delhi

\section{KEY WORDS}

- case study

- confirmatory research

- EU policies

- exploratory research

- methodology

- policy process

- quantitative methods

\section{Forum Section}

\section{The Study of EU Public Policy}

\author{
Results of a Survey
}

\section{Fabio Franchino}

University College London, UK

\section{ABSTRACT}

This note reports the results of a survey of all the articles on EU policies published since 1994 in three major journals. It makes four recommendations. We should probably invest more research time on (1) established policy areas that are at the core of the Union, (2) the study of policy adjudication and the role of courts in the EU policy process, (3) confirmatory theory-testing research and (4) strategies that increase the number of observations, in order to make more use of statistical estimation techniques. 
How do we research EU policies? Which policies and policy processes do we analyse? How do we structure our research? In this note, I report the results from a survey of the EU policy literature. I analyse the substantive coverage of the literature and the structure and methods that we use. I conclude with four recommendations for future research.

\section{Data set}

I have analysed all the articles published since 1994 in the Journal of Common Market Studies (JCMS) and the Journal of European Public Policy (JEPP) and, since 2000, in European Union Politics (EUP). I have disregarded editorials and contributions to the sections on Review, European Agenda and Annual Review of Activities of JCMS, Review and Research News of JEPP and Forum in EUP. I have included in the data set only articles where the analysis of at least one EU policy has a non-trivial or tangential importance to the relevant contribution. I have disregarded articles centred only on national policies, purely theoretical works and studies that contribute solely to the economics or business literature. For instance, Winkler's (1999) formal model on the Maastricht Treaty and Economic and Monetary Union (EMU) and Dunning's (1997) work on the impact of the single market on foreign direct investment have not been included.

Since 1994, 234 articles that dedicate a non-trivial section to the study of at least one EU policy have been published, an annual average of 21 articles. Figure 1 illustrates a moderately increasing trend. Throughout the past 10 years, approximately $30 \%$ of all the publications in these three journals examine at least one EU policy. Hence, this field is important for our understanding of the EU.

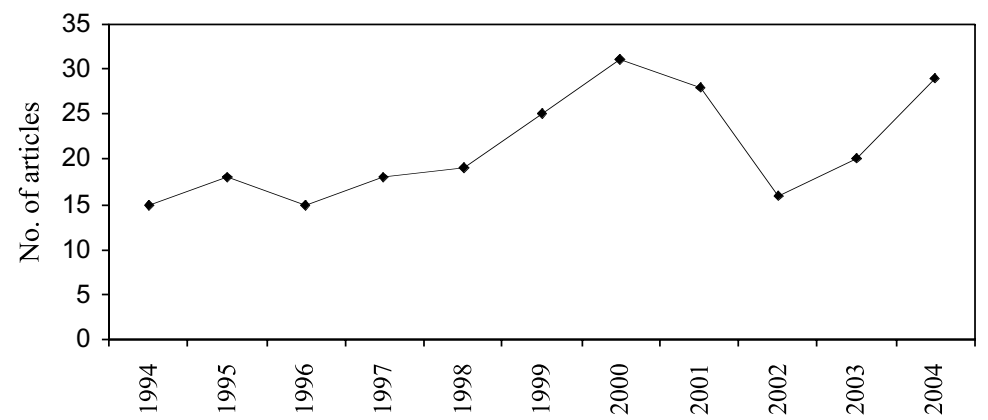

Figure 1 Trends in the study of EU policies. 
Table 1 Policy areas

\begin{tabular}{|c|c|}
\hline Policy areas & $\begin{array}{l}\text { No. of } \\
\text { articles }\end{array}$ \\
\hline Environment & 34 \\
\hline EMU and GSP & 21 \\
\hline Regional policy & 19 \\
\hline Social policy & 18 \\
\hline CFSP; commercial policy & 15 \\
\hline Immigration and asylum; telecoms; transport & 12 \\
\hline Agriculture; R\&D & 9 \\
\hline Competition & 8 \\
\hline \multicolumn{2}{|c|}{ Development and aid; employment; external economic relations; } \\
\hline Energy; ESDP; food safety & 5 \\
\hline \multicolumn{2}{|c|}{$\begin{array}{l}\text { Audio-visual and media; banking; corporate governance; movement of } \\
\text { services; taxation; technology and innovation }\end{array}$} \\
\hline $\begin{array}{l}\text { Exchange rate; fisheries; JHA; mutual recognition } \\
\text { public procurement; state aid }\end{array}$ & 3 \\
\hline \multicolumn{2}{|c|}{$\begin{array}{l}\text { Data protection; financial markets; gender equality; health and safety; } \\
\text { insurance; movement of goods; public health; single market; } \\
\text { steel and coal; TENs }\end{array}$} \\
\hline $\begin{array}{l}\text { Aerospace; AIDS/HIV policy; biotechnology; cons } \\
\text { cultural policy; education; industrial policy; int } \\
\text { movement of capital; postal services; professic } \\
\text { voluntary sector }\end{array}$ & 1 \\
\hline \multicolumn{2}{|l|}{ Broader groupings of some areas } \\
\hline EMU, GSP and exchange rate & 23 \\
\hline Social policy, employment and gender & 23 \\
\hline Trade and external economic relations & 20 \\
\hline Utilities and network industries & 15 \\
\hline Justice and home affairs & 14 \\
\hline Research, technology and innovation & 13 \\
\hline Goods, standards and mutual recognition & 12 \\
\hline Health and consumer protection & 12 \\
\hline Transport and TENs & 12 \\
\hline Banking, insurance, capital and securities & 9 \\
\hline Services, professions and movement of persons & 9 \\
\hline
\end{tabular}

\section{Policy areas}

Table 1 lists, in descending order of coverage, the policy areas that are analysed by these articles. A work can cover more than one policy area (e.g. Héritier, 1997). In the upper part of the table, I have simply adopted the 
author's own classification. However, I have then aggregated some policy areas into broader categories in the lower portion of the table. ${ }^{1}$

Environmental policy clearly tops the table. With 34 articles covering it from different perspectives, it is by far the most-researched policy area. A distant, second group includes EMU and social, trade and regional policy, broadly construed. Each area is analysed by between 19 and 23 articles. Common foreign and security policy (CFSP), regulation of utilities and network industries (telecommunications, energy and postal services), justice and home affairs (JHA), research and technology, standards and movement of goods, health, consumer protection and transport are moderately researched, with between 12 and 15 articles analysing these policies. The remaining areas are essentially under-researched. Among these, there are some long-established policies such as agriculture, competition, movement of persons and of services, qualifications and professions, fisheries, public procurement and state aid.

It could be argued that one explanation of this coverage is the time horizon of the survey. Newly established policies are likely to receive more attention. This undoubtedly applies to EMU, CFSP, JHA, utilities regulation and consumer protection. But this conjecture explains only part of the story. Fisheries and public procurement, two under-researched policy areas, are as old as the intensively investigated environmental and regional policies.

There are some worrying signs that we are spending too much time and resources on some clearly secondary policies and ignoring core ones. Some undeniably important areas, such as agriculture, competition and free movement, deserve at least as much attention as does social policy. In my view, the fact that there are twice as many articles on the European employment strategy as an open method of coordination (OMC) as there are on state aid is problematic. I recognize the novelty of the OMC. It is intellectually stimulating and deserves our scrutiny, but, in my view, the life of the average European is likely to be more profoundly affected by the EU control of state aid. And data and empirical evidence are certainly not lacking. Plenty of important measures and policy decisions have been taken over the past 10 years that are worth analysing.

\section{Policy process}

I have also analysed the stages of the policy process on which the articles concentrate. Roughly following Howlett and Ramesh (2003), I have identified three broad categories. The first, termed policy design, covers anything from agenda-setting, formulation, advocacy and lobbying up to policy-making, which would normally include the adoption of legislative measures and the 


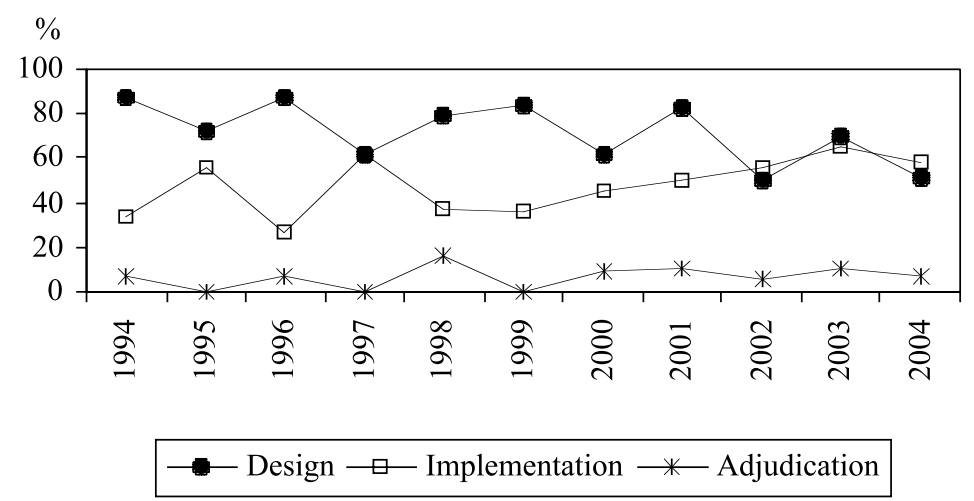

Figure 2 Trends in the study of the EU policy process.

establishment of institutions or working procedures. The second category is policy implementation, which also includes policy evaluation and analysis of policy outcomes. The third category is policy adjudication. It records cases where judicial decisions are subject to analysis. The categories are not mutually exclusive; for instance, an article could cover both design and implementation (e.g. Payne, 2000).

More than $70 \%$ of the articles focus on policy design, the first stage of the policy process. About half of the articles cover policy implementation as well, but only about $7 \%$ deal with policy adjudication. As illustrated in Figure 2, policy design is the stage of the policy process on which the majority of the articles concentrate. Its share always exceeded 50\% throughout the decade. Policy implementation comes second but, on two occasions over the past three years, more articles have focused on policy implementation than on policy design. In my view, there appears to be a welcome trend of the academic community gradually shifting attention from design to implementation. Policy adjudication comes a distant third, never exceeding $16 \%$. One reason for this outcome is probably that judicial politics is marginal or irrelevant to developments in some policy areas such as CFSP. A second, equally plausible, reason is that regulatory policies, which are the core of the EU and where adjudication is of crucial importance, are not studied enough.

\section{Theory testing}

Articles have also been evaluated as to whether they attempt to carry out a full-blown test of a specific theory. I used the category full testing if an article 


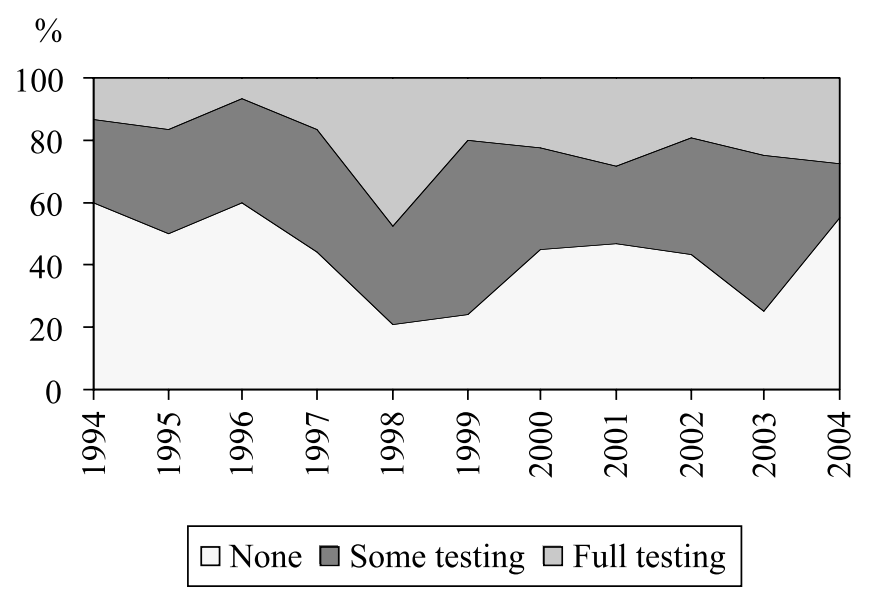

Figure 3 Trends in theory testing.

contains a comprehensive literature review from which clear expectations are derived. These hypotheses are then subsequently subject to a systematic empirical test (e.g. Dudley and Richardson, 1999). Some testing is used if there is some attempt to engage and test the theoretical literature (e.g. Schmidt, 2002); none is used where such an attempt is minimal or non-existent (e.g. Curwen, 1995). Categories are mutually exclusive and, undoubtedly, there is an element of subjectivity in this classification because I cannot claim to be an expert in all the theories of the policy process. Moreover, this categorization is not synonymous with quality nor is it a judgement of academic rigour. An atheoretical study can be an insightful and revealing description of a policy, and a full-blown hypothesis-testing exercise could be fundamentally flawed.

About $43 \%$ of the articles do not engage the theoretical literature, $34 \%$ relate partially to theories of the policy process, and only $23 \%$ embark on a full-blown hypothesis-testing exercise. No specific trends seem to emerge, as Figure 3 illustrates. Undeniably, purely descriptive and exploratory works, which may be unrepresentative but add depth to our substantive knowledge of EU policies, are valuable. However, there is room for improvement. There is no reason why those works that partially engage the literature could not develop into proper full-blown and systematic theory-testing exercises. There is room for a much larger share of these types of works in the literature. I suspect that the prevalence of atheoretical studies is the result of the tendency to focus on newly established or secondary policies where data and theories are in short supply. 


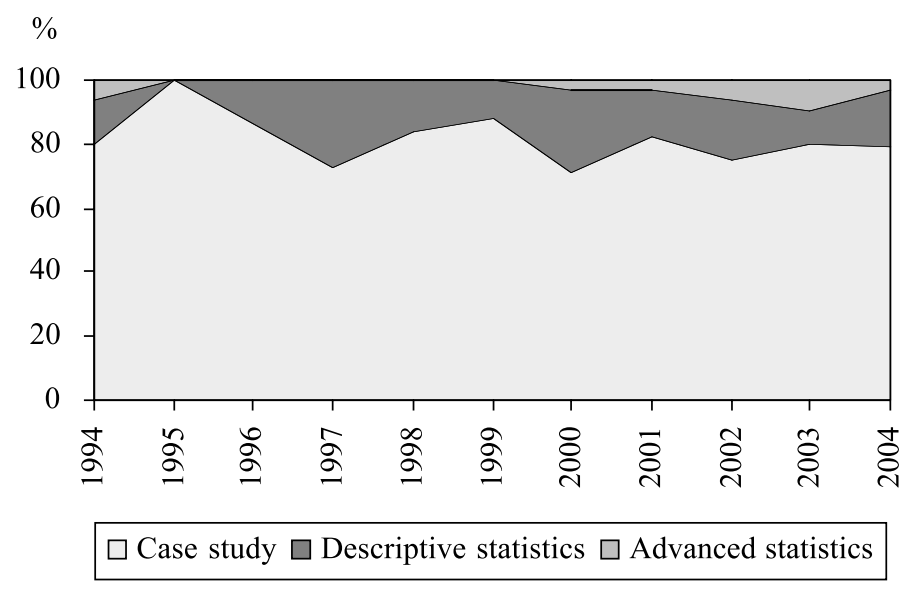

Figure 4 Trends in methodology.

\section{Methodology}

Finally, I have coded the articles according to the methodology used. Case study includes qualitative works with a small N (e.g. Héritier, 1997; Schmidt, 2002), descriptive statistics is for studies that provide larger- $N$ data sets (e.g. Wise, 2000), and the category advanced statistics records works that use large$N$ data sets to carry out any type of inferential analysis, from standard regression to multidimensional scaling (e.g. Zanger, 2000). Categories are mutually exclusive. Hence, for instance, the work of Wise (2000), which is based on a qualitative analysis but also provides descriptive statistics, is assigned only to the second category. My work (Franchino and Rahming, 2003), which includes a qualitative analysis of legislation and some regressions, is assigned only to advanced statistics. Again, no judgement of quality is made in this codification as a study could be applying the incorrect estimation technique to the data set or the operationalization could be flawed.

The large majority of the EU policy research, $81 \%$, is based on the casestudy method. About $16 \%$ of the articles provide descriptive statistics of some kind, and less than 3\% use more advanced techniques. Figure 4 shows that there has been no substantial change in these percentages over the years, although advanced techniques appear to be gradually replacing descriptive statistics.

The case-study method has its strengths. It provides greater depth of analysis, cases are more easily comparable, and causal mechanisms can be more clearly elucidated through, for instance, process-tracing and 
pattern-matching. Moreover, it is particularly apt for testing invariant causal relationships, namely those based on necessary, sufficient or necessary and sufficient arguments (Gerring, 2004). However, the method also has its weaknesses. It suffers from the inability to support broad and well-bounded propositions, it tends to lack representativeness, and causal effects and probabilistic causal relations cannot be estimated (George and Bennett, 2004; Gerring, 2004). The preponderance of this method in the study of EU policies is likely to be related to the preference, at least within this academic community, for descriptive rather than causal inference, as shown in the previous section. Moreover, the focus on newer policies tends to generate exploratory rather than confirmatory research. We also have limited useful variance (e.g. CFSP is a unique experiment in foreign policy cooperation, and there are no other comparable cases we can rely on). The case-study method, as a research strategy, has strong affinities with single-unit exploratory research (Gerring, 2004). Nevertheless, there seems to be a need to rebalance this trend and pursue strategies to increase the number of observations. In my view, we need more confirmatory, large- $N$ research based on causal inferences, broad and well-bounded propositions and representative samples that allow us to estimate probabilistic causal relations.

\section{Conclusion}

The results from this survey of the literature can be summarized in four points and recommendations:

- The research on EU policies tends to focus on newer and, in some cases, secondary areas. Some older policies are over-researched, others are neglected. For a better understanding of the EU policy outcomes, we should probably invest more of our scarce resources in these latter areas that are at the core of the Union.

- Policy design and implementation are becoming equally important. This is a welcome trend. Yet, especially with regard to regulatory policies, the role of national and supranational courts in the EU policy process probably deserves greater attention by the academic community.

- There is a need for a more systematic shift from exploratory or descriptive to confirmatory theory-testing research. Theory generation has played, and will still play, an invaluable part in our understanding of the EU. As Gerring (2004: 349) puts it, 'many works in social science, including most generally acknowledged classics, are seminal works ... Pathbreaking research is, by definition, exploratory.' In my view, however, 
there is room for more well-structured and systematic hypothesis-testing works on EU policies.

- Finally, we should consider more seriously strategies that increase the number of observations in our research and, thus, make more extensive use of statistical estimation techniques. Of course, the estimates and inferences of quantitative models are not flawless and they are only as good as our operationalization, measurement, data sources and estimation techniques. Nevertheless, the case-study method has serious flaws too and its predominance in the literature seems unwarranted.

\section{Note}

1 In most cases, it is self-explanatory which policies the broader categories group together. However, to further clarify, trade and external economic relations includes commercial policy (in addition to external economic relations); utilities and network industries includes postal services, energy and telecoms; justice and home affairs includes immigration and asylum; research, technology and innovation includes biotechnology, intellectual property and R\&D; goods, standards and mutual recognition includes audiovisual and media; health and consumer protection includes AIDS/HIV policy, food safety and data protection; finally, banking, insurance, capital and securities includes financial markets.

\section{References}

Curwen, Peter (1995) 'Telecommunications Policy in the European Union: Developing the Information Superhighway', Journal of Common Market Studies 33(3): 331-60.

Dudley, Geoffrey and Jeremy Richardson (1999) ‘Competing Advocacy Coalitions and the Process of "Frame Reflection": A Longitudinal Analysis of EU Steel Policy', Journal of European Public Policy 6(2): 225-48.

Dunning, John H. (1997) 'The European Internal Market Programme and Inbound Foreign Direct Investment', Journal of Common Market Studies 35(1): 1-30.

Franchino, Fabio and Anne J. Rahming (2003) 'Biased Ministers, Inefficiency, and Control in Distributive Policies: An Application to the EU Fisheries Policy', European Union Politics 4(1): 11-36.

George, Alexander L. and Andrew Bennett (2004) Case Studies and Theory Development. Cambridge, MA: MIT Press.

Gerring, John (2004) 'What Is a Case Study and What Is It Good For?', American Political Science Review 98(2): 341-54.

Héritier, Adrienne (1997) ‘Policy-Making by Subterfuge: Interest Accommodation, Innovation and Substitute Democratic Legitimation in Europe - Perspectives from Distinctive Policy Areas', Journal of European Public Policy 4(2): 171-89. 
Howlett, Michael and M. Ramesh (2003) Studying Public Policy: Policy Cycles and Policy Subsystems. Oxford: Oxford University Press.

Payne, Dexter C. (2000) 'Policy-Making in Nested Institutions: Explaining the Conservation Failure of the EU's Common Fisheries Policy', Journal of Common Market Studies 38(2): 303-24.

Schmidt, Susanne K. (2002) 'The Impact of Mutual Recognition - Inbuilt Limits and Domestic Responses to the Single Market', Journal of European Public Policy 9(6): 935-53.

Winkler, Bernhard (1999) 'Is Maastricht a Good Contract?', Journal of Common Market Studies 37(1): 39-58.

Wise, Mark (2000) 'The Atlantic Arc: Transnational European Reality or Regional Mirage?', Journal of Common Market Studies 38(5): 865-90.

Zanger, Sabine C. (2000) 'Good Governance and European Aid. The Impact of Political Conditionality', European Union Politics 1(3): 293-317.

\section{About the author}

Fabio Franchino is Lecturer in Political Science and Director of the Master in European Public Policy, University College London, 29/30 Tavistock Square, London, WC1H 9EZ, UK.

Fax: +44 2076794969

E-mail: f.franchino@ucl.ac.uk 